\title{
Progress in tumor-derived exosome miRNA regulating tumor metastasis research
}

\author{
Shuanglong $\mathrm{Du}^{1, \uparrow}$, Yuqing $\mathrm{Li}^{2, \dagger, *}$ \\ ${ }^{1}$ School of Shanxi Medical University, Taiyuan, Shanxi 030001, China; \\ ${ }^{2}$ School of Jilin University, Changchun, Jilin 130012, China; \\ ${ }^{\dagger}$ These authors contributed equally.
}

\begin{abstract}
Tumor metastasis is the most important biological feature of a malignant tumor. It is also a complex process involving multi-step, multi-gene, and multi-products. Tumor cell-derived exosomes are vesicles secreted by tumor cells, containing proteins, lipids, noncoding RNA, and other components. MicroRNA (miRNA) of tumor cell-derived exosomes affects the tumor cell microenvironment and participates in tumor metastasis by activating various signaling pathways. Here, we summarize the miRNA and its related pathways that affect many factors of tumor metastasis and discuss the role of tumor-derived miRNA in the treatment and prevention of tumor metastasis. We also conclude the targets of tumor-derived miRNA in recent years. This article can provide new ideas for the development of tumor metastasis targeting drugs in the future.
\end{abstract}

\section{INTRODUCTION}

Tumor metastasis is when malignant tumor cells migrate from the primary site to other sites and continue to grow through lymphatic, vascular, or coelomic pathways[1]. Tumor metastasis begins with tumor cells invading surrounding normal tissues, then infiltrating into blood vessels and moving to other circulatory system parts. Subsequently, tumor cells infiltrate into distant organs, stay in target organs, and form tumor precursor positions. After a period of dormancy, tumor cells wake up in distant organs and form metastases[2]. Studies have shown that cancer metastasis accounts for $90 \%$ of deaths among tumor patients, and about $60 \%$ of cancer patients have occurred tumor metastasis at the initial diagnosis[3]. Therefore, it is of great significance to study the targeting of tumor metastasis.

The variety and quantity of exosome-derived miRNA may be closely related to tumor size, malignant degree, invasion, metastasis, and stage and grade[4, 5]. In recent years, it found that exosomes secreted by tumor cells transmit information between tumor cells and normal cells through their contents, which play a significant role in tumor cell metastasis[6]. Exosomes are lipid bilayer vesicles with a diameter of 30-150 nm, secreted into the extracellular matrix by budding after the fusion of intracellular multi-vesicular and plasma membrane[5]. Exosomes are commonly used as intercellular transfer carriers of cytoplasmic proteins, nucleic acids, and lipids which widely exist in blood, urine, saliva, and other biological fluids[7]. They can transmit the information from donor cells to recipient cells and mediate intercellular communication[8]. Exosomes contain proteins, cytokines, transcription factor receptors, RNA, and other bioactive substances, and protein and RNA are the main components. According to coding ability, RNA can be divided into mRNA with the protein-coding ability and ncRNA without protein-coding capacity. MicroRNA (miRNA, miR-) is a kind of endogenous ncRNA with a length of about 20-24 nucleotides[5]. It can bind to the 3'UTR of multiple target mRNAs, resulting in aberrant target gene expression, which plays a role similar to tumor suppressor gene and oncogene, and has an impact on the process of tumor metastasis[9].

In this review, we focus on the following aspects of miRNA's influence on tumor metastasis. EMT is induced by regulating the expression of Snail, PTEN, and $\beta$ Catenin to induce tumor metastasis. Extracellular matrix remodeling is induced by changing the state of fibroblasts and vascular endothelial cells in the tumor microenvironment to induce tumor metastasis. Normal lymphocytes such as dendritic cells, T lymphocytes, macrophages are used or changed to provide favorable conditions for tumor metastasis. We hope to summarize the related tumor-derived exosome miRNA and its mechanism of action, which can reference future research of tumor metastasis targeted drugs.

\section{2 miRNA and epithelial mesenchymal transition}

Generally, epithelial cells have apical-basal polarity and are connected with desmosomes by adhesion[10].

\footnotetext{
* Corresponding author: liyq1318@mails.jlu.edu.cn
} 
However, after epithelial-mesenchymal transition (EMT), epithelial cells will lose this original characteristic and show the characteristics of mesenchymal cells under the action of some factors. Early tumor cells will appear obvious EMT phenomenon, this process also makes tumor cells obtain certain motility and invasiveness. As a result, their adhesion ability decreased and motility enhanced[11], making it easier for tumor cells to separate from the tissue[12], then invading the surrounding normal tissues, and starts the process of tumor metastasis. Tumor exosomes can mediate this process associated with normal cells by carrying miRNA, participating in the EMT process, and affecting the expression of some EMT indicators, such as E-cadherin $\mathrm{N}$-cadherin, vimentin, and $\beta$-catenin[13]. The miRNAs involved in this section are summarized in the table 1.

\subsection{Snail family protein}

Human Snail family proteins are a class of transcription inhibitors. The zinc finger domain of its carboxyl terminal binds to the CAGGTG sequence in the promoter region of E-cadherin to down regulate Ecadherin expression and start EMT[14].

Sun et al. found that in human non-small cell lung cancer, miR-346 promotes the process of EMT by inhibiting XPC, an important DNA damage recognition factor that has a close relationship with cancer metastasis, up-regulating Snail expression, and down-regulating Ecadherin expression[15]. In contrast, miR-30a inhibits the expression of Snail 1 through the p53 pathway and up-regulates the expression of E-caking the expression of Tet1[16]; Meanwhile, miR-153 has also shown to inhibit snail 1[17].

\subsection{PTEN}

PTEN gene is a kind of tumor suppressor gene. Its expression product inhibits the proliferation and invasion of tumor cells by inhibiting PI3K/Akt pathway. At the same time, more and more clinical scholars recognize that PTEN and EMT-related gene expression changes are related to the occurrence and development of some tumors. However, the upstream mechanism of regulating PTEN and EMT-related gene expression has not been clarified[18].

Yang et al. found that the metastatic ability of hepatoma cells treated with exosomes of high metastatic hepatoma cells (Huh7 and SK-Hep-1 cells) in vitro was significantly higher than those treated with exosomes of low metastatic hepatoma cells (hep-3b cells). Furthermore, by sequencing the exosome miRNA of hepatoma cell, they found that the expression of miR$92 a-3 p$ in exosomes of high metastatic hepatoma cells was significantly increased. Subsequently, the author's team predicted and confirmed that PTEN is the target of tumor-derived exosomal miR-92a-3p through Western blot and immunofluorescence detection, and using miRDB, miRWalk, TargetScan, and miRTarBase databases. By targeting PTEN and regulating its downstream Akt / snail signaling pathway, miR-92a-3p can promote EMT in receptor cells[19].

\section{$2.3 \beta$-catenin}

$\beta$-catenin is a form of cytoplasmic plaque protein that can connect cadherin adhesion receptors to the cytoskeleton. It can bind to the E-cadherin on the membrane, which is very important for the positioning and function of E-cadherin. At the same time, it is also a key element in the WNT signal pathway[20]. In normal epithelium and non-invasive cancer cells, $\beta$-catenin exists in the cell membrane. However, after the occurrence of EMT, $\beta$-catenin will be separated from Ecadherin and translocated into the nucleus, promoting the induction of gene transcription of EMT-related proteins[21].

Zhang et al. determined the targeting relationship between miR-1255b-5p and human telomerase reverse transcriptase (hTERT) in colorectal cancer by screening serum samples from patients with colorectal cancer. The study found that miR-1255b-5p inhibits the expression of EMT-related genes and $\beta$-catenin by silencing the expression of hTERT, which further inhibits the EMT process[22]. Yu found in hepatoma cells that hypoxiainduced exosome miR-1273f could target the downregulation of $\mathrm{WNT} / \beta$-catenin signaling pathway inhibitor LHX6 expression. In turn, the $\mathrm{WNT} / \beta$-catenin signaling pathway is activated, and $\beta$-catenin expression is upregulated, eventually leading to EMT[23].

Recently, You et al. used deep RNA sequencing to find that TGF- $\beta 1$ stimulated cervical cancer cells to secrete more exocrine bodies containing miR-663b. Next, they used online bioinformatics tools and dual-luciferase report analysis to identify MGAT3 as a new direct target for miR-663b. It has been shown that MGAT3 (mannoside acetylglucosamine transferase 3) may be a transfer suppressor gene[24]. Then, exocrine PKH67 labeling test and wound healing and Transwell analysis confirmed that exocrine miR-663b might be swallowed by cervical cancer cells and then affected its migration and invasion function. In the final experiment, the expression of miR-663b and MGAT3 and the regulation of the EMT pathway caused by MGAT3 were detected by quantitative real-time transcription-polymerase chain reaction (qPCR) and western blot analysis. This experiment has confirmed that tumor-derived exosomal miR-663b is endocytosed by cervical cancer cells adjacent or distant after TGF- $\beta 1$ exposure and inhibits the expression of MGAT3, thereby accelerating the EMT process and ultimately promoting local and distant metastasis[25].

\subsection{TGF- $\beta$}

Transforming growth factor $\beta$ (TGF- $\beta$ ) is a cytokine that regulates cell proliferation, migration, and differentiation of many different cell types. After binding to its receptor, TGF- $\beta$ family proteins promote the phosphorylation of intracellular signal effector protein SMAD carboxylterminal and make it form a trimer complex, which leads 
to nuclear translocation and regulates the transcription of target genes. Under the action of TGF- $\beta$, the SMAD complex can activate the expression of EMT transcription factors and promote the occurrence of EMT[26].

Bai et al. found that HCT-116 cells (human colorectal cancer cell line), which have undergone EMT, can secrete exosomes containing a large number of miR$128-3 p$. Then they found that miR-128-3p could downregulate the expression of FOXO4 and induce the activation of TGF- $\beta /$ SMAD and JAK/STAT3 signaling pathways, resulting in EMT. At the same time, this exosome carrying a mass of miR-128-3p can infect normal HCT-116 cells, thus promoting the formation of translocation[27]. Similarly, $\mathrm{Qu}$ found that tumorderived exosome miR-93 reduces the expression of NEDD4L by binding to the mRNA's 3'-UTR of NEDD4L, thus preventing NEDD4L from degrading activated SMAD2/SMAD3 (a downstream transcription factor of TGF- $\beta$ ). The protection of SMAD2/SMAD3 by miR-93 maintains the signal transduction of the TGF- $\beta$ pathway, which promotes EMT induced by TGF- $\beta$ [28].

Table 1 miRNA involved in EMT

\begin{tabular}{|c|c|c|c|c|}
\hline $\begin{array}{c}\text { Exosome comp } \\
\text { onent }\end{array}$ & $\begin{array}{l}\text { Cancer } \\
\text { type }\end{array}$ & $\begin{array}{c}\text { Relevant } \\
\text { targets }\end{array}$ & $\begin{array}{c}\text { Functi } \\
\text { on }\end{array}$ & $\begin{array}{c}\text { Referen } \\
\text { ce }\end{array}$ \\
\hline miR-346 & $\begin{array}{l}\text { non-small } \\
\text { cell lung } \\
\text { cancer }\end{array}$ & $\begin{array}{l}\text { XPC, } \\
\text { Snail }\end{array}$ & $\begin{array}{c}\uparrow \\
\text { EMT }\end{array}$ & {$[15]$} \\
\hline miR-30a & -- & $\begin{array}{l}\text { p53, } \\
\text { Snail }\end{array}$ & $\begin{array}{c}\downarrow \\
\text { EMT }\end{array}$ & {$[14,16]$} \\
\hline miR-153 & -- & -- & $\begin{array}{c}\downarrow \\
\text { EMT }\end{array}$ & [17] \\
\hline miR-92a-3p & $\begin{array}{c}\text { high } \\
\text { metastatic } \\
\text { liver } \\
\text { cancer }\end{array}$ & $\begin{array}{l}\text { PTEN, } \\
\text { Akt/Snail }\end{array}$ & $\begin{array}{c}\uparrow \\
\text { EMT }\end{array}$ & [19] \\
\hline miR-1255b-5p & $\begin{array}{c}\text { colorectal } \\
\text { cancer }\end{array}$ & $\begin{array}{l}\text { hTERT, } \\
\beta \text {-catenin }\end{array}$ & $\begin{array}{c}\downarrow \\
\text { EMT }\end{array}$ & [22] \\
\hline miR-1273f & $\begin{array}{l}\text { liver } \\
\text { cancer }\end{array}$ & $\begin{array}{l}\text { LHX6 } \\
\text { Wnt/ } \beta- \\
\text { catenin }\end{array}$ & $\begin{array}{c}\uparrow \\
\text { EMT }\end{array}$ & [23] \\
\hline miR-663b & $\begin{array}{c}\text { cervical } \\
\text { carcinoma }\end{array}$ & $\begin{array}{c}\text { TGF- } \\
\beta 1, \\
\text { MGAT3 }\end{array}$ & $\begin{array}{c}\uparrow \\
\text { EMT }\end{array}$ & {$[24,25]$} \\
\hline miR-128-3p & $\begin{array}{l}\text { colorectal } \\
\text { cancer }\end{array}$ & $\begin{array}{c}\text { FOXO4 } \\
, \\
\text { TGF- } \\
\beta / \text { SMAD } \\
, \\
\text { JAK/STA } \\
\text { T3 }\end{array}$ & $\begin{array}{c}\uparrow \\
\text { EMT }\end{array}$ & [27] \\
\hline miR-93 & lung cancer & $\begin{array}{c}\text { NEDD4L } \\
\text { SMAD2 / } \\
\text { SMAD3 } \\
, \\
\text { TGF- } \beta\end{array}$ & $\begin{array}{c}\uparrow \\
\text { EMT }\end{array}$ & [28] \\
\hline
\end{tabular}

\section{MiRNA and Tumor microenvironment (TME)}

Tumor microenvironment (TME) refers to the cellular environment surrounding the lesion site of the primary tumor. TME is a complex and heterogeneous environment, including cancer cells, endothelial cells, immune cells and cancer-related fibroblasts (CAF), extracellular matrix (ECM), and other substances secreted in tissue space. Therefore, changes in TME are closely related to tumor progression[29]. This section mainly introduces CAF and endothelial cells. The miRNAs involved in this section are summarized in table 2.

\section{1 cancer-related fibroblasts (CAF)}

Recent studies have shown that CAF plays a crucial role in tumorigenesis and metastasis. It is the most abundant stromal cell in the tumor microenvironment[30]. CAF promotes tumor cell proliferation by producing ECM proteins (collagen, fibronectin) and proteases, which play a significant role in extracellular matrix (ECM) remodeling [31].

Tumor-derived exosome miRNA plays an essential role in reprogramming normal fibroblasts (NF) into CAF. Wang et al. found that gastric cancer cell-derived exosome miR-27a can bind to the 3'-UTR of CSRP2 and reduce its protein level. It induces NF reprogramming to $\mathrm{CAF}$ and promotes cancer cells' proliferation, movement, and metastasis[32]. MiR-9 directly targets E-cadherin (CDH1), resulting in increased motility and invasiveness of cancer cells. Meanwhile, Baroni found that in breast cancer, miR-9 is involved in microenvironment reprogramming by converting NF to CAF[33]. At the same time, some experiments have shown that miR-9 delivered to endothelial cells and effectively reduced SOCS5 levels, leading to an activated JAK-STAT pathway. This signaling cascade promoted endothelial cell migration and tumor angiogenesis[34]. In addition, in Yang's experiment, exosomes were extracted from normal breast epithelial cells, breast cancer (BC) cells, and BC cells with miR-146a overexpression or knockdown using multi-step differential centrifugation. The morphology and size of exosomes were observed by TEM and particle size analysis. Next, Researchers injected BC mouse models with DIR labeled exosomes. And they detected the EMT of BC cells by PCR and western blot. And cell invasion and migration abilities were determined by scratch test and Transwell assay. It was finally confirmed that miR-146a in the exosomes of BC cells could activate the $\mathrm{Wnt} / \beta$-catenin signaling pathway. It promotes the transformation of $\mathrm{NF}$ into $\mathrm{CAF}$ and changes the tumor microenvironment[35]. Zhou found that miR-21 decreased PTEN expression in hepatocellular carcinoma-derived exosomes. Furthermore, PTEN activated PDK1/Akt signaling pathway to transform hepatic stellate cells into CAF[36]. Fang et al. found that miR-1247-3p, an exosomal miRNA of high metastatic hepatocellular carcinoma, can target the down-regulation of B4GALT3 ( $\beta-1$, 4galactosyltransferase III). It phosphorylates $\mathrm{NF}-\kappa \mathrm{B}$, which in turn stimulates the $\beta 1$-integrin-NF- $\kappa \mathrm{B}$ signaling pathway in NF to activate $\beta 1$-integrin, and finally transforms NF cells into $\mathrm{CAF}$ [37]. Fan found that in lung cancer, miR-210 induces NF reprogramming into proangiogenic CAF by directly targeting TET2 and 
activating the JAK2/STAT3 signaling pathway. Finally, it promotes lung cancer angiogenesis[38].

\subsection{Vascular endothelial cells}

Vascular endothelial cells are monolayer flat epithelium located on the inner surface of the heart, blood vessels, and lymphatics, constituting the inner wall of blood vessels. The formation of new blood vessels in tumors is crucial for tumor progression. In the tumor microenvironment, the blood vessels supply oxygen and nutrients necessary for the growth of tumor cells, remove wastes, and provide a pathway for tumor metastasis. Studies have found that in breast cancer, lung cancer, rectal cancer, gastric cancer, chronic myelogenous leukemia, and other tumors, tumor-derived exosomal miRNA can change vascular permeability, promote angiogenesis, and provide a pathway for tumor metastasis.

In breast cancer cells, Zhou et al. found that exosomes containing miR-105 reduced the expression of tight junction protein ZO-1 in endothelial cells. Furthermore, the tight junction of endothelial cells and vascular integrity were damaged, and vascular permeability was enhanced. Finally, tumor cells infiltrate into the blood vessels and promote the occurrence of metastasis[39]. In another experiment, Yang found that exosomes of gastric cancer cells deliver miR-130a to endothelial cells. They using bioinformatics tools confirmed that the 3'-UTR of mRNA directly targeted and down-regulated c-MYB (a transcription factor involved in various biological behaviors in cells and closely associated with angiogenesis). Finally, angiogenesis and tumor metastasis are promoted[40]. Yang et al. found that exosome miR-103 secreted by HCC cells increased vascular permeability and promoted tumor metastasis by targeting multiple endothelial junction proteins[41]. Meanwhile, Zhou found that miR155-5p, a melanoma cell-derived exosome, could activate the pro-angiogenesis of CAF. In turn, the JAK2/STAT3 signaling pathway was activated to promote the expression of vascular endothelial growth factor A (VEGFA), fibroblast growth factor 2 (FGF2), and matrix metalloproteinase-9 (MMP9). Finally, angiogenesis is promoted[42]. Hsu et al. found that hypoxia led to significant upregulation of miR-23a in exosomes of lung cancer cells. MiR-23a increases angiogenesis by directly inhibiting its target prolyl hydroxylases 1 and 2 (pHD1 and 2), leading to the accumulation of hypoxia-inducible factor $1 \alpha(\mathrm{HIF}-1 \alpha)$ in endothelial cells. At the same time, this study also found that miR-23a increased vascular permeability by inhibiting the expression of tight junction protein ZO-1 and provided conditions for transendothelial migration of cancer cells[43].

Table 2 miRNA related to the tumor microenvironment

\begin{tabular}{|c|c|c|c|c|}
\hline $\begin{array}{c}\text { Exosome c } \\
\text { omponent }\end{array}$ & $\begin{array}{c}\text { Cancer } \\
\text { type }\end{array}$ & $\begin{array}{c}\text { Relevant } \\
\text { targets }\end{array}$ & Function & Reference \\
\hline miR-27a & $\begin{array}{c}\text { gastric } \\
\text { cancer }\end{array}$ & CSRP2 & $\begin{array}{c}\text { promote } \\
\text { the } \\
\text { formation } \\
\text { of CAF }\end{array}$ & {$[32]$} \\
\hline
\end{tabular}

\begin{tabular}{|c|c|c|c|c|}
\hline miR-9 & $\begin{array}{l}\text { breast } \\
\text { cancer }\end{array}$ & $\begin{array}{l}\text { CDH1, } \\
\text { JAK- } \\
\text { STAT }\end{array}$ & $\begin{array}{l}\text { promote } \\
\text { the } \\
\text { formation } \\
\text { of CAF, } \\
\text { endothelia } \\
1 \text { cell } \\
\text { migration, } \\
\text { and tumor } \\
\text { angiogene } \\
\text { sis }\end{array}$ & {$[33,34]$} \\
\hline miR-146a & $\begin{array}{l}\text { breast } \\
\text { cancer }\end{array}$ & $\begin{array}{l}\text { Wnt/ } \beta- \\
\text { catenin }\end{array}$ & $\begin{array}{l}\text { promote } \\
\text { the } \\
\text { formation } \\
\text { of CAF }\end{array}$ & [35] \\
\hline miR-21 & $\begin{array}{l}\text { hepatocell } \\
\text { ular } \\
\text { carcinoma }\end{array}$ & $\begin{array}{c}\text { PTEN, } \\
\text { PDK1/AK } \\
\text { T }\end{array}$ & $\begin{array}{l}\text { promote } \\
\text { the } \\
\text { formation } \\
\text { of CAF }\end{array}$ & [36] \\
\hline $\begin{array}{c}\text { miR-1247- } \\
3 p\end{array}$ & $\begin{array}{c}\text { highly } \\
\text { metastatic } \\
\text { hepatocell } \\
\text { ular } \\
\text { carcinoma }\end{array}$ & $\begin{array}{c}\text { B4GALT3 } \\
\text { NF-кB }\end{array}$ & $\begin{array}{l}\text { promote } \\
\text { the } \\
\text { formation } \\
\text { of CAF }\end{array}$ & [37] \\
\hline miR-210 & $\begin{array}{l}\text { lung } \\
\text { cancer }\end{array}$ & $\begin{array}{c}\text { JAK2/ST } \\
\text { AT3 }\end{array}$ & $\begin{array}{l}\text { promote } \\
\text { the } \\
\text { formation } \\
\text { of CAF }\end{array}$ & [38] \\
\hline miR-105 & $\begin{array}{l}\text { breast } \\
\text { cancer }\end{array}$ & ZO1 & $\begin{array}{l}\text { impaired } \\
\text { vascular } \\
\text { integrity }\end{array}$ & [39] \\
\hline miR-130a & $\begin{array}{l}\text { gastric } \\
\text { cancer }\end{array}$ & C-MYB & $\begin{array}{l}\text { promote } \\
\text { angiogene } \\
\text { sis }\end{array}$ & [40] \\
\hline miR-103 & $\begin{array}{l}\text { liver } \\
\text { cancer }\end{array}$ & $\begin{array}{c}\text { A variety } \\
\text { of } \\
\text { endothelia } \\
1 \\
\text { connexins }\end{array}$ & $\begin{array}{c}\text { enhance } \\
\text { vascular } \\
\text { permeabili } \\
\text { ty }\end{array}$ & [41] \\
\hline $\begin{array}{c}\mathrm{miR}-155- \\
5 \mathrm{p}\end{array}$ & $\begin{array}{l}\text { melanoma } \\
\text { cells }\end{array}$ & $\begin{array}{l}\text { JAK2/ST } \\
\text { AT, } \\
\text { VEGFA } \\
\text { etc. }\end{array}$ & $\begin{array}{l}\text { promote } \\
\text { angiogene } \\
\text { sis }\end{array}$ & [42] \\
\hline miR-23a & $\begin{array}{l}\text { lung } \\
\text { cancer }\end{array}$ & $\begin{array}{l}\text { PHD1, } \\
\text { PHD2, } \\
\text { ZO-1 }\end{array}$ & $\begin{array}{c}\text { enhance } \\
\text { vascular } \\
\text { permeabili } \\
\text { ty }\end{array}$ & [43] \\
\hline
\end{tabular}

\section{MiRNA and tumor-associated immune cells}

In the process of tumor metastasis, tumor cells transform the anti-tumor activity of immune cells through tumorderived exosome miRNA, such as affecting the development and function of dendritic cells, affecting the differentiation and development of T-lymphocytes, and regulating the transformation of macrophage subtypes, to promote their growth and metastasis[44]. The miRNAs involved in this section are summarized in table 3.

\subsection{Dendritic cells (DCs)}

Dendritic cells can efficiently deliver antigens. Immature dendritic cells can capture antigens, recognize and bind microorganisms, inflammatory factors, viruses, and other substances through toll-like receptors (TLRs) to activate and mature[45]. Mature dendritic cells can induce initial $\mathrm{T}$ lymphocytes to differentiate into different subtypes by secreting specific cytokines and/or costimulatory molecules [46]. Tumor-derived exosome miRNA can 
affect this process, and then change the monitoring and clearance function of lymphocytic tumor cells.

Relevant studies have shown that miR-21 and miR$29 \mathrm{a}$ in exosomes of non-small lung cancer cells can down-regulate the expression of TLRs, thus affecting the function of $\mathrm{T}$ lymphocytes and promoting tumor proliferation and metastasis. The overexpression of miR203 in pancreatic cancer can also achieve the same results[47]. Jin et al. found that in the study of cervical cancer cells, HMGB1 can promote DC maturation. Studies have shown that miR-34a can target downregulate the expression of HMGB1, thereby inhibiting DC maturation. Currently, 5-aminolevulinic acid photodynamic therapy, which is widely used in treating cervical cancer, achieves the treatment of cervical cancer by inhibiting miR-34[48].

\subsection{T lymphocytes}

In the thymic microenvironment, thymocytes recognize the affinity of $\mathrm{T}$ cell receptor (TCR) and peptide MHC complex (pMHC) on the surface of antigen-presenting cell (APC) to select the appropriate T cells. Only T cells with moderate affinity can avoid apoptosis and continue to mature. According to the phenotype of TCR, mature T lymphocytes can be divided into $\mathrm{CD}^{+} \mathrm{T}$ cells $(\mathrm{CD} 4+$ CD8 -), CD8 ${ }^{+} \mathrm{T}$ cell (CD4 - CD8 +)[49].

\subsubsection{CD4 $4^{+}$T cells}

$\mathrm{CD}^{+} \mathrm{T}$ cells are important regulators of immune response and inflammatory diseases[50]. Signals transmitted by CD4+ $\mathrm{T}$ can activate downstream toxic $\mathrm{T}$ cells $\left(\mathrm{CD}^{+} \mathrm{T}\right.$ cells). Th17 differentiated from initial $\mathrm{CD}^{+} \mathrm{T}$ cells has been proved to have a proinflammatory effect[51]. It has been confirmed that inflammation plays a significant role in the process of tumor metastasis[52]. Tumor-derived miRNA can promote the process of tumor metastasis by influencing the differentiation of $\mathrm{CD}^{+} \mathrm{T}$ cells into pro-inflammatory phenotype and inducing apoptosis of $\mathrm{CD}^{+} \mathrm{T}$ cells.

In the aspect of inflammatory phenotype transformation: MiR-301a may inhibit the IL-6-induced STAT3 pathway by downregulating PIAS3 and promote the formation of Th17[53]. Zhou et al. showed that miR$29 a-3 p$ and miR-21-5p synergistically target STAT3 in $\mathrm{CD}^{+} \mathrm{T}$ cells. After binding with it, cytokines IL-4, IL-6, and TNF- $\alpha$ down-regulated expression and up-regulated expression of anti-inflammatory factor IL-10 lead to the imbalance of Treg/Th17, increased phenotypic differentiation of Th17, and promote the process of tumor metastasis[54]. In terms of inducing $T$ cell apoptosis: MiR-690 released from mouse melanoma cell-derived exosomes to $\mathrm{CD}^{+} \mathrm{T}$ cells may downregulate the expression of anti-apoptotic proteins Bcl-2, Mcl-1, and Bcl XL of $\mathrm{CD}^{+} \mathrm{T}$ cells, which leads to $\mathrm{CD}^{+} \mathrm{T}$ cell apoptosis[55]. Hsa-miR-20a-5p regulates JAK/STAT signaling pathway by targeting the JAK1 gene, which leads to the phosphorylation of STAT protein in $\mathrm{CD}^{+} \mathrm{T}$ cells and affects $\mathrm{T}$ cell differentiation, thereby affecting the body's anti-tumor ability[56].

\subsection{2 $C D 8^{+} T$ cell}

$\mathrm{CD}^{+} \mathrm{T}$ cells protect the body by eliminating viruses and cancer cells[57]. The weakening of their functions is not conducive to the monitoring and clearance of tumors. Ye et al. found that in NPC-related studies, tumor exosome miR-24-3p inhibits the regulation of $\mathrm{CD}^{+} \mathrm{T}$ cells and $\mathrm{CD}^{+} \mathrm{T}$ cells on tumor pathogenesis by directly targeting down-regulation of FGF11 expression[58]. Vignard and his colleagues found that Hsa-miR-498 in melanoma cell-derived exosomes can reduce the secretion of TNF- $\alpha$ by $\mathrm{CD}^{+} \mathrm{T}$ cells . Thus, the killing effect of $\mathrm{CD} 8^{+} \mathrm{T}$ on the tumor is reduced; Hsa-miR-3187-3p carried by melanoma exosomes inhibits the signal transduction in $\mathrm{CD}^{+} \mathrm{T}$ cells and hinders the development of $\mathrm{CD}^{+} \mathrm{T}$ cells by reducing the expression of CD45 and the dephosphorylation of Src family protein tyrosine kinases[59].

\subsection{Macrophages}

In the tumor microenvironment, tumor-associated macrophages (TAM) exist in M1 and M2 subtypes[60]. M1 is a pro-inflammatory phenotype and has an anticancer function. In contrast, M2 phenotype can promote tumor cell metastasis by promoting angiogenesis, mediating cell escape from apoptosis, and inhibiting adaptive immune response[61, 62]. Macrophages are the capital immune cells closely related to tumor entry, and exosomes play a critical role in activating macrophages[63]. Below, we focus on the association between exosome miRNA and M2 polarization.

Downregulation of tumor-derived exosome miRNA on macrophage polarization protein PTEN can lead to activation of PI3K/Akt and STAT3 signaling pathways and ultimately enhance the accumulation of tumorpromoting factors such as IL10, CCL2, and VEGF-A, and make macrophages transform from tumor inhibition to tumor promotion. Baig et al. showed that miR-21 was closely related to the M2 polarization of TAM. Firstly, miR-21 recruits TAMs through two signaling events: It promotes the formation of a migration niche. MiR-21 inhibits the expression of tumor suppressors (including PTEN, PDCD4, IGFBP3, etc.) by directly binding to the mRNA 3'-UTR of macrophages, thus providing favorable conditions for the formation of pre-migration niche, and increase the secretion of cancer promoting factors (such as CCL2, CCL5, and IL-8). The recruited Tam further recognizes miR-21, leading to the upregulation of M2 markers such as Mrc1, CD163, and IL10 , resulting in $\mathrm{M} 2$ polarization, thereby promoting tumor progression. By regulating the expression of PTEN, exosome-derived miR-103a in lung cancer ultimately leads to the accumulation of tumor-promoting factors such as IL10, CCL2, and VEGF-A, which reduces the anti-tumor immune response[64]. Liu et al. found that endoplasmic reticulum stressed hepatoma cells transfer exosomes miR-23a-3p to macrophages, and through inhibiting PTEN to activate the PI3K-Akt pathway, macrophages undergo M2 polarization. That increases the expression of programmed death receptor 1 (PD-L1) in macrophages, thereby inhibiting $\mathrm{T}$ cell 
function and affecting tumor immunity[65]. Zhao et al. also found a similar regulation mode in the related research of colorectal cancer exosomes miR-934: miR934 induces M2 polarization by downregulating the expression of PTEN and activating PI3K/Akt signaling pathway. The research further found that hnRNPA2B1 can mediate the packaging of miR-934 into the exosomes of colorectal cancer cells by combining with the GGAG sequence of miR-934. It also mediates exosomes transfer to macrophages[66].

On the contrary, tumor-derived exosome miRNA can also transform M2 macrophages into tumor suppressor phenotype: In the experimental results on breast cancer cells, Moradi chaleshtori et al. found that overexpression of miR-130 and miR-33 in exosomes ingested by breast cancer cells (MDA-MB-231 cells) can transform M2 polarized TAMs into M1 phenotype, to delay the development of tumor[67].

Table 3 immune cell related miRNAs

\begin{tabular}{|c|c|c|c|c|}
\hline $\begin{array}{c}\text { Exosome } \\
\text { compone } \\
\text { nt }\end{array}$ & Cancer type & $\begin{array}{c}\text { Relevant } \\
\text { targets }\end{array}$ & Function & Reference \\
\hline $\begin{array}{c}\text { miR-21 } \\
\text { and miR- } \\
29 a\end{array}$ & $\begin{array}{l}\text { non-small } \\
\text { lung cancer }\end{array}$ & TLRs & $\begin{array}{l}\text { affect the } \\
\text { function } \\
\text { of } \mathrm{T} \\
\text { lymphoc } \\
\text { ytes }\end{array}$ & [47] \\
\hline miR-203 & $\begin{array}{l}\text { pancreatic } \\
\text { cancer }\end{array}$ & TLRs & $\begin{array}{l}\text { affect the } \\
\text { function } \\
\text { of } \mathrm{T} \\
\text { lymphoc } \\
\text { ytes }\end{array}$ & [47] \\
\hline miR-34a & $\begin{array}{c}\text { cervical } \\
\text { cancer cells }\end{array}$ & HMGB1 & $\begin{array}{c}\text { inhibit } \\
\text { DC } \\
\text { maturatio } \\
n\end{array}$ & [48] \\
\hline miR-301a & -- & $\begin{array}{l}\text { STAT3, } \\
\text { PIAS3, } \\
\text { Th17 }\end{array}$ & $\begin{array}{c}\text { promote } \\
\text { the } \\
\text { formation } \\
\text { of Th17 }\end{array}$ & [53] \\
\hline $\begin{array}{c}\text { miR-29a- } \\
3 p \text { and } \\
\text { miR-21- } \\
5 p\end{array}$ & -- & $\begin{array}{l}\text { TNF a, } \\
\text { IL- } \\
4,6,10, \\
\text { STAT3 }\end{array}$ & $\begin{array}{l}\text { promote } \\
\text { the } \\
\text { formation } \\
\text { of Th17 }\end{array}$ & [54] \\
\hline miR-690 & melanoma & $\begin{array}{l}\text { Bcl-2, } \\
\text { Mcl-1, } \\
\text { Bcl XL }\end{array}$ & $\begin{array}{l}\text { lead to } \\
\mathrm{CD}^{+} \mathrm{T} \\
\text { cell } \\
\text { apoptosis }\end{array}$ & [55] \\
\hline $\begin{array}{l}\text { Hsa-miR- } \\
20 a-5 p\end{array}$ & -- & $\begin{array}{c}\text { JAK/ST } \\
\text { AT }\end{array}$ & $\begin{array}{l}\text { affect } \mathrm{T} \\
\text { cell } \\
\text { differenti } \\
\text { ation }\end{array}$ & [56] \\
\hline $\begin{array}{c}\text { miR-24- } \\
3 p\end{array}$ & -- & FGF11 & $\begin{array}{l}\text { inhibit } \\
\text { the } \\
\text { regulatio } \\
\mathrm{n} \text { of } \\
\mathrm{CD} 4^{+} \mathrm{T} \\
\text { cells and } \\
\mathrm{CD} 8^{+} \mathrm{T} \\
\text { cells on } \\
\text { tumor } \\
\text { pathogen } \\
\text { esis }\end{array}$ & [58] \\
\hline $\begin{array}{l}\text { Hsa-miR- } \\
498\end{array}$ & melanoma & TNF & $\begin{array}{l}\text { reduce } \\
\text { the } \\
\text { killing } \\
\text { effect of } \\
\mathrm{CD} 8^{+} \mathrm{T} \\
\text { cell }\end{array}$ & [59] \\
\hline
\end{tabular}

\begin{tabular}{|c|c|c|c|c|}
\hline $\begin{array}{l}\text { Hsa-miR- } \\
3187-3 \mathrm{p}\end{array}$ & melanoma & $\begin{array}{l}\text { CD45, } \\
\text { Src } \\
\text { family } \\
\text { protein } \\
\text { tyrosine } \\
\text { kinases }\end{array}$ & $\begin{array}{l}\text { inhibit } \\
\text { the signal } \\
\text { transducti } \\
\text { on in } \\
\mathrm{CD}^{+} \mathrm{T} \\
\text { cells and } \\
\text { hinder } \\
\text { the } \\
\text { developm } \\
\text { ent of } \\
\mathrm{CD} 8^{+} \mathrm{T} \\
\text { cells }\end{array}$ & [59] \\
\hline miR-21 & -- & $\begin{array}{l}\text { PTEN, } \\
\text { PDCD4, } \\
\text { IGFBP3, } \\
\text { Chemoki } \\
\text { nes etc. }\end{array}$ & $\begin{array}{c}\text { recruit } \\
\text { macropha } \\
\text { ge and } \\
\text { promote } \\
\text { M2 } \\
\text { polarizati } \\
\text { on }\end{array}$ & [64] \\
\hline miR-103a & lung cancer & $\begin{array}{c}\text { IL10, } \\
\text { CCL2, } \\
\text { VEGF-A }\end{array}$ & $\begin{array}{c}\text { promote } \\
\text { M2 } \\
\text { polarizati } \\
\text { on of } \\
\text { macropha } \\
\text { ges } \\
\end{array}$ & [64] \\
\hline $\begin{array}{c}\text { miR-23a- } \\
3 p\end{array}$ & hepatoma & $\begin{array}{l}\text { PTEN, } \\
\text { PI3K-Akt }\end{array}$ & $\begin{array}{l}\text { promote } \\
\text { M2 } \\
\text { polarizati } \\
\text { on of } \\
\text { macropha } \\
\text { ges }\end{array}$ & [65] \\
\hline miR-934 & $\begin{array}{c}\text { colorectal } \\
\text { cancer }\end{array}$ & $\begin{array}{c}\text { PTEN, } \\
\text { PI3K/Akt } \\
\text { hnRNPA } \\
\text { 2B1 }\end{array}$ & $\begin{array}{c}\text { promote } \\
\text { M2 } \\
\text { polarizati } \\
\text { on of } \\
\text { macropha } \\
\text { ges }\end{array}$ & [66] \\
\hline $\begin{array}{l}\text { miR-130 } \\
\text { and miR- } \\
\quad 33\end{array}$ & $\begin{array}{l}\text { breast } \\
\text { cancer }\end{array}$ & -- & $\begin{array}{c}\text { transform } \\
\text { M2 } \\
\text { polarized } \\
\text { TAMs } \\
\text { into M1 } \\
\text { phenotyp } \\
\text { e }\end{array}$ & [67] \\
\hline
\end{tabular}

\section{Conclusions}

Exosome miRNA can regulate the expression of downstream pathways by blocking target mRNA. MiRNA delivered by tumor exosomes can regulate a large part of tumor metastasis factors. Also, blocking related miRNA can inhibit tumor metastasis to a certain extent. However, due to the complexity of tumor metastasis mechanism and the uncertainty of experimental conditions in vivo and in vitro, most of the studies on tumor-derived exosome miRNA are still in the laboratory stage. Most of them are in vitro experiments few can clarify the mechanism.But, it is certain that with the gradual clarification of the mechanism of miRNA action, the inhibitors designed for tumor-derived exosome miRNA will have broad application prospects in the future. For example, the combination of multiple miRNA inhibitors can achieve the purpose of regulating multiple tumor metastasis pathways. At the same time, it can also solve the problem of tumor drug resistance and escape caused by the current anti-tumor targeted drugs acting on a single target. After clarifying the sorting pathway of miRNA in exosomes, it can directionally inhibit miRNA from entering exosomes, thus avoid the negative effect of miRNA on target cells. Moreover, 
some tumor-derived miRNAs can serve as tumor markers, which can easily and accurately screen a specific type of tumor. MiRNA also has a definite development space in tumor detection.

\section{References}

1. Jia, C., J. Wei, and H. Xiaobo, Research Progress of exocrine in Digestive tract tumor Metastasis\% J Laboratory Medicine. 2020. 35(12): p. 1220-1223.

2. Jingfeng, Z., et al., Endoplasmic reticulum stress and tumor metastasis\%JJournal of Sichuan University (Medical Edition). 2021. 52(01): p. 11-15.

3. Yang, J., et al., Abstract 1526: KPNA4 promotes prostate cancer metastasis through TNFAB mediated cytokine crosstalk in tumor microenvironment \%J Cancer Research. 2016. 76(14_Supplement).

4. Hui, T., et al., Research progress of exosomalderived microRNAs in disease diagnosis and treatment. Journal of Central South University (Medical Science), 2015. 40(11): p. 1270-1275.

5. Jiajia, J., et al. Research progress of exosome noncoding RNA in tumor. in The 4th International Conference on Public Health and Medical Sciences 2019. 2019. Xi 'an, Shaanxi, China.

6. Xiao, L., et al., Endometrial Cancer Cells Promote M2-Like Macrophage Polarization by Delivering Exosomal miRNA-21 under Hypoxia Condition. J Immunol Res, 2020. 2020: p. 9731049.

7. Jie, H., et al., Research progress in exosome extraction and preservation techniques. Chinese Journal of Cell Biology, 2021. 43(02): p. 451-459.

8. Maas, S.L.N., X.O. Breakefield, and A.M. Weaver, Extracellular Vesicles: Unique Intercellular Delivery Vehicles. Trends Cell Biol, 2017. 27(3): p. 172-188.

9. Juxian, D., et al., Research progress of oncogenic exosomal miRNAs in regulating vascularization of bone malignancies. Journal of Clinical Oncology, 2021. 26(01): p. 84-88.

10. Nieto, M.A., et al., EMT: 2016. Cell, 2016. 166(1): p. 21-45.

11. Xiaochao, L., et al., Research progress on the role of stromal cell regulated EMT in tumor invasion and metastasis. Life science, 2021. 33(01): p. 95-103.

12. Dongre, A. and R.A. Weinberg, New insights into the mechanisms of epithelial-mesenchymal transition and implications for cancer. Nat Rev Mol Cell Biol, 2019. 20(2): p. 69-84.

13. Li, L., et al., Exosomes Derived from Hypoxic Oral Squamous Cell Carcinoma Cells Deliver miR-21 to Normoxic Cells to Elicit a Prometastatic Phenotype. Cancer Res, 2016. 76(7): p. 1770-80.

14. Barrallo-Gimeno, A. and M.A. Nieto, The Snail genes as inducers of cell movement and survival: implications in development and cancer. Development, 2005. 132(14): p. 3151-61.
15. Sun, C.C., et al., MicroRNA-346 facilitates cell growth and metastasis, and suppresses cell apoptosis in human non-small cell lung cancer by regulation of XPC/ERK/Snail/E-cadherin pathway. Aging (Albany NY), 2016. 8(10): p. 2509-2524.

16. Yang, R., et al., Correlation Between SingleNucleotide Polymorphisms Within miR-30a and Related Target Genes and Risk or Prognosis of Nephrotic Syndrome. DNA Cell Biol, 2018. 37(3): p. 233-243.

17. Li, Q., et al., Suppression of epithelial-mesenchymal transition in hepatocellular carcinoma cells by Krüppel-like factor 4. Oncotarget, 2016. 7(20): p. 29749-60.

18. Nan-mi-wei, L., et al., Correlation of miR-221 expression level with PTEN/Akt signaling pathway and EMT-related gene expression in glioma tissue. Journal of Hainan Medical College, 2016. 22(20): p. 2369-2372.

19. Yang, B., et al., High-metastatic cancer cells derived exosomal miR92a-3p promotes epithelialmesenchymal transition and metastasis of lowmetastatic cancer cells by regulating PTEN/Akt pathway in hepatocellular carcinoma. Oncogene, 2020. 39(42): p. 6529-6543.

20. Gavert, N. and A. Ben-Ze'ev, beta-Catenin signaling in biological control and cancer. J Cell Biochem, 2007. 102(4): p. 820-8.

21. Liu, F., et al., Biomarkers for EMT and MET in breast cancer: An update. Oncol Lett, 2016. 12(6): p. 4869-4876.

22. Zhang, X., et al., Exosomal miR-1255b-5p targets human telomerase reverse transcriptase in colorectal cancer cells to suppress epithelial-to-mesenchymal transition. Mol Oncol, 2020. 14(10): p. 2589-2608.

23. Yu, Y., et al., Hypoxia-induced exosomes promote hepatocellular carcinoma proliferation and metastasis via miR-1273f transfer. Exp Cell Res, 2019. 385(1): p. 111649.

24. Huang, H., et al., MiR-23a transcriptional activated by Runx 2 increases metastatic potential of mouse hepatoma cell via directly targeting Mgat3. Sci Rep, 2018. 8(1): p. 7366.

25. You, X., et al., Exosomal miR-663b exposed to TGF- $\beta 1$ promotes cervical cancer metastasis and epithelial-mesenchymal transition by targeting MGAT3. Oncol Rep, 2021. 45(4).

26. Wenhao, C., Y. Ming, and Z. Yanqiao, Research progress on the mechanism of epithelialmesenchymal transformation in malignant tumors. China tumor, 2016. 25(01): p. 51-57.

27. Bai, J., et al., Exosomal miR-128-3p Promotes Epithelial-to-Mesenchymal Transition in Colorectal Cancer Cells by Targeting FOXO4 via TGF$\beta /$ SMAD and JAK/STAT3 Signaling. Front Cell Dev Biol, 2021. 9: p. 568738.

28. Qu, M.H., et al., miR-93 promotes TGF- $\beta$-induced epithelial-to-mesenchymal transition through 
downregulation of NEDD4L in lung cancer cells. Tumour Biol, 2016. 37(4): p. 5645-51.

29. Li, K., et al., Exosomes play roles in sequential processes of tumor metastasis. Int J Cancer, 2019. 144(7): p. 1486-1495.

30. Togo, S., et al., Carcinoma-associated fibroblasts are a promising therapeutic target. Cancers (Basel), 2013. 5(1): p. 149-69.

31. Cirri, P. and P. Chiarugi, Cancer-associatedfibroblasts and tumour cells: a diabolic liaison driving cancer progression. Cancer Metastasis Rev, 2012. 31(1-2): p. 195-208.

32. Wang, J., et al., Exosomal miR-27a Derived from Gastric Cancer Cells Regulates the Transformation of Fibroblasts into Cancer-Associated Fibroblasts. Cell Physiol Biochem, 2018. 49(3): p. 869-883.

33. Baroni, S., et al., Exosome-mediated delivery of miR-9 induces cancer-associated fibroblast-like properties in human breast fibroblasts. Cell Death Dis, 2016. 7(7): p. e2312.

34. Zhuang, G., et al., Tumour-secreted miR-9 promotes endothelial cell migration and angiogenesis by activating the JAK-STAT pathway. Embo j, 2012. 31(17): p. 3513-23.

35. Yang, S.S., et al., Breast cancer-derived exosomes regulate cell invasion and metastasis in breast cancer via miR-146a to activate cancer associated fibroblasts in tumor microenvironment. Exp Cell Res, 2020. 391(2): p. 111983.

36. Zhou, Y., et al., Hepatocellular carcinoma-derived exosomal miRNA-21 contributes to tumor progression by converting hepatocyte stellate cells to cancer-associated fibroblasts. J Exp Clin Cancer Res, 2018. 37(1): p. 324.

37. Fang, T., et al., Tumor-derived exosomal miR-1247$3 p$ induces cancer-associated fibroblast activation to foster lung metastasis of liver cancer. Nat Commun, 2018. 9(1): p. 191.

38. Fan, J., et al., miR-210 transferred by lung cancer cell-derived exosomes may act as proangiogenic factor in cancer-associated fibroblasts by modulating JAK2/STAT3 pathway. Clin Sci (Lond), 2020. 134(7): p. 807-825.

39. Zhou, W., et al., Cancer-secreted miR-105 destroys vascular endothelial barriers to promote metastasis. Cancer Cell, 2014. 25(4): p. 501-15.

40. Yang, H., et al., Exosome-Derived miR-130a Activates Angiogenesis in Gastric Cancer by Targeting C-MYB in Vascular Endothelial Cells. Mol Ther, 2018. 26(10): p. 2466-2475.

41. Fang, J.H., et al., Hepatoma cell-secreted exosomal microRNA-103 increases vascular permeability and promotes metastasis by targeting junction proteins. Hepatology, 2018. 68(4): p. 1459-1475.

42. Zhou, X., et al., Melanoma cell-secreted exosomal miR-155-5p induce proangiogenic switch of cancerassociated fibroblasts via SOCS1/JAK2/STAT3 signaling pathway. J Exp Clin Cancer Res, 2018. 37(1): p. 242.

43. Hsu, Y.L., et al., Hypoxic lung cancer-secreted exosomal miR-23a increased angiogenesis and vascular permeability by targeting prolyl hydroxylase and tight junction protein ZO-1. Oncogene, 2017. 36(34): p. 4929-4942.

44. Qin, L., et al., Tumor-associated immune cells promoting Metastasis and targeted Therapy Strategies. Journal of Fudan University (Medical Sciences), 2016. 43(01): p. 104-109+121.

45. den Haan, J.M., R. Arens, and M.C. van Zelm, The activation of the adaptive immune system: cross-talk between antigen-presenting cells, T cells and B cells. Immunol Lett, 2014. 162(2 Pt B): p. 103-12.

46. Qiuyu, W., L. Tete, and C. Jingtao, Regulation of reactive oxygen species on dendritic cells. Chinese Journal of Biochemistry and Molecular Biology: p. $1-12$.

47. Sun, Z., et al., Effect of exosomal miRNA on cancer biology and clinical applications. Mol Cancer, 2018. 17(1): p. 147.

48. Jin, Y., et al., ALA-PDT promotes HPV-positive cervical cancer cells apoptosis and DCs maturation via miR-34a regulated HMGB1 exosomes secretion. Photodiagnosis Photodyn Ther, 2018. 24: p. 27-35.

49. Luckheeram, R.V., et al., CD4 ${ }^{+} \mathrm{T}$ cells: differentiation and functions. Clin Dev Immunol, 2012. 2012: p. 925135.

50. Kimura, A. and T. Kishimoto, IL-6: regulator of Treg/Th17 balance. Eur J Immunol, 2010. 40(7): p. 1830-5.

51. Asadi-Samani, M., et al., Inhibition of Th1 and Th17 Cells by Medicinal Plants and Their Derivatives: A Systematic Review. Phytother Res, 2017. 31(8): p. 1128-1139.

52. Jiejun, L.P.W., Research progress of inflammation and tumor metastasis. Journal of the Second Military Medical University, 2011. 32(01): p. 84-87.

53. Mycko, M.P., et al., MicroRNA-301a regulation of a T-helper 17 immune response controls autoimmune demyelination. Proc Natl Acad Sci U S A, 2012. 109(20): p. E1248-57.

54. Zhou, J., et al., Exosomes Released from TumorAssociated Macrophages Transfer miRNAs That Induce a Treg/Th17 Cell Imbalance in Epithelial Ovarian Cancer. Cancer Immunol Res, 2018. 6(12): p. $1578-1592$.

55. Zhou, J., et al., Melanoma-released exosomes directly activate the mitochondrial apoptotic pathway of CD4(+) T cells through their microRNA cargo. Exp Cell Res, 2018. 371(2): p. 364-371.

56. Ye, S.B., et al., Tumor-derived exosomes promote tumor progression and T-cell dysfunction through the regulation of enriched exosomal microRNAs in human nasopharyngeal carcinoma. Oncotarget, 2014. 5(14): p. 5439-52. 
57. Wells, A.C., E.L. Pobezinskaya, and L.A. Pobezinsky, Non-coding RNAs in CD8 T cell biology. Mol Immunol, 2020. 120: p. 67-73.

58. Ye, S.B., et al., Exosomal miR-24-3p impedes Tcell function by targeting FGF11 and serves as a potential prognostic biomarker for nasopharyngeal carcinoma. J Pathol, 2016. 240(3): p. 329-340.

59. Vignard, V., et al., MicroRNAs in Tumor Exosomes Drive Immune Escape in Melanoma. Cancer Immunol Res, 2020. 8(2): p. 255-267.

60. Cai, J., et al., Oral squamous cell carcinoma-derived exosomes promote M2 subtype macrophage polarization mediated by exosome-enclosed miR29a-3p. Am J Physiol Cell Physiol, 2019. 316(5): p. C731-c740.

61. Wang, X., et al., Hypoxic Tumor-Derived Exosomal miR-301a Mediates M2 Macrophage Polarization via PTEN/PI3K $\gamma$ to Promote Pancreatic Cancer Metastasis. Cancer Res, 2018. 78(16): p. 4586-4598.

62. Yong, Y., et al., Experimental study on polarization of M2 macrophages induced by miR-449 exosomes in colorectal cancer under hypoxic conditions.
International Journal of Laboratory Medicine, 2021. 42(04): p. 421-425.

63. Chanmee, T., et al., Tumor-associated macrophages as major players in the tumor microenvironment. Cancers (Basel), 2014. 6(3): p. 1670-90.

64. Baig, M.S., et al., Tumor-derived exosomes in the regulation of macrophage polarization. Inflamm Res, 2020. 69(5): p. 435-451.

65. Liu, J., et al., Endoplasmic Reticulum Stress Causes Liver Cancer Cells to Release Exosomal miR-23a$3 p$ and Up-regulate Programmed Death Ligand 1 Expression in Macrophages. Hepatology, 2019. 70(1): p. 241-258.

66. Zhao, S., et al., Tumor-derived exosomal miR-934 induces macrophage M2 polarization to promote liver metastasis of colorectal cancer. J Hematol Oncol, 2020. 13(1): p. 156.

67. Moradi-Chaleshtori, M., et al., In vitro and in vivo evaluation of anti-tumoral effect of M1 phenotype induction in macrophages by miR-130 and miR-33 containing exosomes. Cancer Immunol Immunother, 2021. 70(5): p. 1323-1339. 